\title{
Emergent Spaces of Civic Leadership Education and Development: Understanding the Liberal Arts and Humanities from a Perspective of Civic and Public Work
}

\author{
Brandon W. Kliewer \\ Kansas State University \\ bkliewer@ksu.edu \\ Kristin N. Moretto \\ University of South Florida \\ kmoretto@health.usf.edu \\ Jennifer W. Purcell \\ Kennesaw State University \\ jpurce10@kennesaw.edu
}

\begin{abstract}
The value of the liberal arts and humanities has increasingly been called into question on multiple fronts. Attempts to bridge the practical and liberal arts through forms of civic professionalism have been gaining traction in larger spheres of influence. This article outlines the results of a deliberative civic engagement forum $(n=42)$ that created a space for community members from business, education, and non-profit sectors at the National Conference on Service and Volunteerism, to consider the role civic leadership education and development has in liberal arts and humanities programs. The forum was intentionally designed to have participants consider the role of the liberal arts and humanities in redefining the purposes and process of democratic engagement through a lens of civic leadership education and development. This forum was able to gather a group of people from sectors that do not normally speak to the intersection of leadership education and the liberal arts.
\end{abstract}

\section{Introduction}

Civic leadership education and development is critical to addressing $21^{\text {st }}$ century challenges. Civic leadership is broadly understood as being "...a means of sharing responsibility for acting together in pursuit of the common good" (O'Chrislip \& O'Malley, 2013 pg. 1). Marshall Ganz (2010) understands civic leadership as "....accepting responsibility to create conditions that enable others to achieve shared purpose in the face of uncertainty" (p. 527). The project of civic leadership exists with a larger adaptive leadership framework ( $\mathrm{O}^{\prime} \mathrm{Chrislip}$ \& O’Malley, 2013; Heifetz, Grashow, \& Linsky, 2009) and presumes that leadership should be reform orientated and that the activity does not require individuals to act from a position of formal authority.

The challenges society faces are increasingly cross-sector and global in nature. As higher education responds to the emerging needs of a globalized society, educators and institutional 
leaders are exploring innovative approaches to civic leadership education and development. As the need for civic leadership peaks, the structures and purposes of leadership education and development in higher education, tied to a liberal arts and humanities education, becomes more relevant and focused. The value proposition of leadership education and development tied to the liberal arts, humanities, and social sciences is being reexamined. One response to these concerns has been expressed through a growing movement around civic professionalism. Civic professionalism is an attempt to connect the liberal arts with the practical arts in the hope that students will cultivate well-rounded worldviews (Sullivan, 2005; 2008). There is a basic assumption that students with well-developed conceptions of self and a general understanding of their relationship to the larger world will be better prepared to exercise civic leadership. This paper addresses the overarching narrative of civic leadership and subsequent calls for institutions of higher education to better prepare young adults to meet the demands of our global society. The authors present findings from a deliberative civic engagement forum that considered and identified potential pathways to connect civic leadership education and development to the liberal arts and humanities. Using the results from the deliberative civic engagement forum, the authors will conclude with recommendations for future research and practical areas that civic leadership education and development can be integrated into the liberal arts, humanities, and social sciences.

\section{Literature Review}

The relationship between American higher education and market activity is currently in flux. Students increasingly view the undergraduate experience as a path and credential to an improved position in the labor force (Boyle \& Fretz, 2010; Imagining America, 2010; Lagemann \& Lewis, 2011; Sullivan, 2005) and industry is more closely integrated with research activity operating within the academy (Slaugther \& Rhoades, 2004). Furthermore, the shifting relationship between technology, finance, politics, and economics is challenging the liberal education tradition of higher education (Butin, 2013). The future balance between vocational training and traditional liberal arts is currently being redefined.

Recently, a series of attempts have been made to define the future of higher education in ways that do not treat vocational education and liberal arts education as mutually exclusive. There is a growing interest in connecting practical arts with the liberal arts to promote a more holistic and civic-minded development of students. Linking practical arts with liberal arts is often referred to as civic professionalism. William Sullivan (2005) defines civic professionalism as a "social partnership or "social reciprocity" that demands "accountability and responsibility" between professionals and their larger publics (p. 5). Civic professionalism is an approach to teaching and learning that is intended to not only support intellectual maturation, but also civic leadership development (Peter, 2004). The civic professionalism approach to higher education takes the following form: First, students must develop foundational academic knowledge. Second, the curriculum must help students cultivate professional and civic leadership skills. Lastly, the integration of the first two levels of civic professionalism will lead to what Sullivan refers to as "apprentice of purpose" or what others have understood as civic-mindedness (Steinberg, Hatcher, \& Bringle, 2011). 
Civic professionalism intersects civic leadership education when the curriculum and programming includes moral development and civic-minded elements. The adaptive leadership model emphasizes the leadership development of individuals that have a strong sense of social responsibility (Heifetz, Grashow, and Linksy, 2009; Komizes, Lucas, \& McMahon, 2013; Komives \& Wagner, 2009). Furthermore, the use of academic service-learning in leadership education courses has been shown to develop values and socially responsible leadership in students (Dugan, Kodama, \& Corrieda, 2013; Priest, Bauer, \& Fine, 2015).

The literature in leadership education that does consider community engagement focuses on the arrange of learning experiences. Buschlen, Warner, \& Goffnetts (2015) indicate that leadership education experiences that includes a humanitarian service-learning component centers learning around the experience of the natural disaster, privilege, and personal transformation through the community engagement experience. This research is in line with other projects that indicate leadership education programs that include community engagement help student engage in interdisciplinary spaces, participate in service, work in teams, resolve conflicts, and understand group dynamics (Grunell, 2015; Polk, 2014).

Leadership educators are increasingly connecting the study and practice of leadership to civic-mindedness and social responsibility. Leadership educators are making this link by including forms of community engagement into the curriculum and programming. For the purpose of this study, community engagement describes "... collaboration between institutions of higher education and their larger communities (local, regional/state, national, global) for the mutually beneficial exchange of knowledge and resources in a context of partnership and reciprocity" (NERCHE). These levels of civic professionalism are thought to help students internalize ethical norms and link their academic knowledge to a higher calling that supports the public good. Current approaches to civic professionalism, represented by IUPUI's civicmindedness rubric (Steinberg, 2008), are strong in conceptualizing learning goals and outcomes such as awareness of personal values, commitment to service, and understanding community issues, but are not intended to consider how student learning will translate to changed behaviors in the future. An orientation to civic professionalism will not only improve the relevance of student learning outcomes, but also prepare students to alter their behaviors in ways that will improve their ability to exercise leadership in civic and public spaces. Priest, Bauer, and Fine (2015) have demonstrated the positive impact community engagement can have in introductory leadership courses in developing pathways to civic-minded and social responsible leadership. There have been efforts to understand how faculty development and academic markets impact the infrastructure around civic professionalism and, ultimately, student development (O'Meara \& Jaeger, 2006; O’Meara, 2011). However, to this point, the leadership studies literature has not tracked or mapped the ways leadership education and development fits within civic professionalization. Current research in the field of leadership education has only really begun to map approaches to civic engagement in leadership education courses (Johnson \& Woodard, 2014). The existing focus on civic engagement in leadership education in centered around skill, practices, and civic approaches that currently exist and are need to navigate civic and public spaces. This stream of inquiry would consider how leadership activity challenges traditional roles within systems to include civic and public purposes. Identifying as a civic professional creates a basis of public life, but having skills attitudes, and agency to create spaces for civic professionalism requires higher levels of behavioral change. 


\section{Methods}

Research Partnership. The research partnership began with representatives from Deloitte, Points of Light, Florida Gulf Coast University, University of North Carolina Greensboro, and Kennesaw State University. Two of the researchers accepted positions at Kansas State University and University of South Florida as the research was being completed. This partnership was formed to consider the potential role civic leadership education and development could have in the liberal arts, from the perspective of the social sector from the National Conference on Volunteerism and Service.

Use of Deliberative Civic Engagement Methods. The conveners emphasized a scholarly design that was anchored to principles of inclusion and participation. The approach of this deliberative civic engagement forum, now referred to as civic dialogue, found its relevance in defining the scholarly process in relation to the purposes and process of democratic practice (Saltmarsh \& Hartley, 2011). A commitment to building a dialogue and participatory structure was present at each stage of the scholarly process. Through a collaborative process, the conveners identified intergroup-dialogue techniques as the best way to create a participatory space to map the intersects of community engagement and civic leadership education and development. Intergroup dialogues "...carefully examine a problem and arrive at a well-reasoned solution after a period of inclusive, respectful consideration of diverse points of view." (Gastil, 2008 p. 8). The intergroup dialogue technique is situated within a larger landscape of deliberative civic engagement.

The lead researchers for the study developed a framing document that intended to focus participants' attention on the relationship between civic leadership education and the liberal arts, humanities, and social sciences. The framing document was designed to be broad enough to allow participants to bring their own understanding of the issue to the discussion, but specific enough to concentrate the discussion on germane topics. The framing document was leveraged to create infrastructure for the intergroup dialogue. Trained facilitators extended the quality and length of the dialogue.

Six undergraduate students from Kennesaw State University's pilot Civic Leadership, Engagement and Research Undergraduate Research Program were trained as facilitators. Students invited to participate had sophomore and junior status and were experienced in leadership and community engagement programs at Kennesaw State University. The facilitation training was conducted in a small group setting and amounted to approximately 2 hours of instruction. The training covered general approaches to deliberative civic engagement (Nabatchi, 2012) and practical strategies to facilitate intergroup dialogue. The students were given the framing document and strategies to capture the results of the dialogue using a field note method (Emerson, Fretz, \& Shaw, 1995). Students were encouraged to review the materials leading up to the intergroup dialogue.

Setting. The dialogue was convened at the Points of Light National Conference on Volunteerism and Service (NCVS). The NCVS is the largest convening of service and volunteer service leaders in the world. It showcases the ways service, volunteerism, and forms of community engagement are being used to solve challenging community problems. The 2014 
Conference on Volunteerism and Service was held in Atlanta, Georgia on June 16, 2014 to June 18, 2014. The National Conference on Service and Volunteerism conference offered a unique opportunity to bring together an over representation of non-profit leaders, government officials, and representatives from the business sector to engage in dialogue around the relationship between the liberal arts, humanities, and civic leadership. The NCVS attracts participants that do not normally participate in higher education conversations of liberal arts and civic leadership education. The community perspective represented by the National Conference on Volunteerism and Service participants shed light on different ways to think and understand the larger purposes of civic leadership education as the practice is connected to the liberal arts. A majority of the participants represent civic engagement sectors, but often only worked with institutions of higher education indirectly as volunteer directors or third-party placement organizations, intermediaries, or cooperating organizations (Duarte, 2015). Our civic dialogue intentionally attempted to overrepresent members of the community in the non-profit, service, governmental, and corporate sectors. Our group leveraged the various voices to generate an authentic conversation about how the liberal arts and humanities is understood through the lens of civic leadership education and development.

Participants. Respondents self-selected to participate in the dialogue session. The civic dialogue session was advertised in the conference proceedings and participants registered for the session in advance of the conference. As a result, participants were able to come to the session primed to discuss the intersection of civic leadership education and civic professionalism connected to the liberal arts, humanities, and social sciences. There were 37 participants and 5 additional conveners. Of the 37 participants, 7 were between the ages of 18-24, 15 were between the ages of 15-34, 7 were between the ages of 45-64, and one person represented the 65-74 age group. Twenty- eight participants self-identified as being female. The remaining 9 participants self-identified as male.

Dialogue Process. David Smith, Acting Director of the Presidio Institute, began the dialogue with a 13 minute provocation. Smith discussed the role cross-sector leadership will have in addressing important issues of the 21 st century. His comments were intended to prime participants to consider how skills and knowledge developed during service and volunteerism experiences can be reimagined. His comments brought attention to the role liberal arts, humanities, and social sciences have in preparing cross-sector leadership.

The participants were then divided into small groups of between 8-9 participants. Each group had at least one facilitator. The facilitators spent 5 minutes reviewing the framing document and the format of the dialogue with their respective small groups. The next 60 minutes was devoted to considering the three questions included in the framing document. At the conclusion of the dialogue session, participants reconvened as an at-large group. During the postdialogue reconvening participants were encouraged to report out and reflect on the outcomes of the small-group dialogue.

Coding Process. The focus of our coding process was to locate civic dialogue instances across the coding framework in Figure 1. Our project was a content analysis of the data that was generated from the deliberative civic engagement activity (Kayser, Lima, \& Lundy, 2013; Holsapple, 2012). We used a constant comparative coding process to make sense of the data 
(Glaser \& Strauss, 2008). A civic dialogue instance was an example, idea, conceptual understanding, or assertion of how civic professionalism or leadership education is understood from the perspective of the participant. The research team led the initial coding and synthesis of the data. All of the notes produced from the dialogue were numbered and collected into a single Adobe PDF document. Using the theoretical framework (see Fig. 1 - at the end of this section), representatives from the university cohort coded instances of the civic dialogue. The goal of the coding process was to map major themes of how participants understood the role civic leadership has and could have in the liberal arts. Each of the university representatives completed the coding process individually and then entered their codes into an excel sheet.

The university representatives convened to identify and discuss the basis of codes that were not consistent across the coders. Agreement between two of the coders was deemed a valid code. In instances of coder disagreement, the three coders discussed the reasoning behind their codes and determined whether the discussion warranted reconsideration. This process was intended to increase the inter-coder reliability of the dialogue results. There were only 3 codes that could not be validated by achieving consensus across the three coders.

Coding Framework. When moving vertically across the coding framework, instances were organized by value or process of democratic engagement. Saltmarsh \& Hartley (2011) informed our conceptual operationalization of purposes and process of democratic engagement. Values/purposes of democratic engagement included but were not limited to, normative positions on how democratic engagement ought to work or which ends democracy ought to work towards. Processes of democratic engagement included procedural understandings and ideas of how democracy works. The values, purposes, and processes of democratic engagement is what attached meaning to the curricular and programmatic goals of civic leadership education. Instances coded within the critical space of the framework often presumed the institution of higher education as having a role in advancing social, political, and economic equity and/or change. The distinction between critical and traditional instances was anchored to the work of Tania Mitchell (2008) and Lori Pompa (2002). Critical instances defined and outlined examples of civic professionalism and leadership that could be integrated into the liberal arts, with the explicit purpose of redefining systems, organizations, and institutions. As such, the critical frame is explicitly connected to exercising leadership for social, political, and economic change. Traditional civic dialogue instances were located within theory and practice within existing societal contexts of skill and knowledge development. The traditional frame emphasized civic leadership education that prepares students to exercise leadership within current systems, organizations, and institutions. Instances coded as traditional often presumed the role of higher education to be limited to general knowledge creations personal development, and including a direct link to professional relevance.

Codes were divided into four categories (values/purposes of democratic engagement, processes of democratic engagement, approach, and practice) with a total of eight possible codes as the researchers distinguished between critical and traditional approaches and practices. Hence, an instance could be coded as one or more of the following eight categories: traditional approach, process of democratic engagement; critical approach, process of democratic engagement; critical approach, values/purpose of democratic engagement; traditional approach, values/purpose of democratic engagement; traditional practice, process of democratic engagement; critical practice, 
process of democratic engagement; critical practice, value/purpose of democratic engagement, traditional practice, value/purpose of democratic engagement.

Movement across the horizontal plain of the coding framework reflected a continuum of theoretical approaches and practice. Codes organized under the "approaches" category included theoretical approaches, concepts, ideas, and abstract concepts. Civic professionalism practices were captured under the "practices" category. Practice includes specific experiences, processes, examples, and circumstances of civic leadership and professionalism.

The following is a representative sample of civic dialogue instances that fit within each area of the coding framework. An example of each of the possible eight categories is presented below:

\begin{tabular}{|c|c|c|c|c|}
\hline \multirow[b]{2}{*}{$\begin{array}{l}\text { Processes } \\
{[1]}\end{array}$} & \multicolumn{2}{|c|}{ Theoretical Approaches } & \multicolumn{2}{|c|}{ Practice } \\
\hline & $\begin{array}{l}\text { Critical 2A } \\
\text { "More cross-sector } \\
\text { curriculum, focused on } \\
\text { critical awareness of } \\
\text { important economic issues. } \\
\text { Students should use their } \\
\text { liberal arts and humanities } \\
\text { education to imagine } \\
\text { alternative economic } \\
\text { systems." }\end{array}$ & $\begin{array}{l}\text { Traditional 1A } \\
\text { "it would be beneficial for } \\
\text { both students and } \\
\text { community to have an } \\
\text { integrated curriculum, } \\
\text { where students could } \\
\text { actively use their education } \\
\text { and community could have } \\
\text { access to critical thinkers } \\
\text { that can actively connect } \\
\text { learning to real-world } \\
\text { issues." }\end{array}$ & $\begin{array}{l}\text { Critical } \\
\text { "institutions need to make } \\
\text { sure that the community is } \\
\text { ready for civic engagement, } \\
\text { and that institutions need to } \\
\text { build a relationship with the } \\
\text { community that would lend } \\
\text { to this work." }\end{array}$ & $\begin{array}{l}\text { Traditional } 1 \mathrm{P} \\
\text { "civic engagement in the } \\
\text { liberal arts provides } \\
\text { application of } \\
\text { professional skills and } \\
\text { experiences that enable } \\
\text { students to articulate } \\
\text { their skills." }\end{array}$ \\
\hline $\begin{array}{l}\text { Values/Purpose } \\
\text { [2] }\end{array}$ & $\begin{array}{l}\text { Critical } \\
\text { "cultivation of a sense of } \\
\text { community, as "same } \\
\text { space" is important to } \\
\text { challenge traditional } \\
\text { understandings of } \\
\text { individualism" }\end{array}$ & $\begin{array}{l}\text { Traditional } 4 \mathrm{~A} \\
\text { "students are engaged in } \\
\text { the community to build } \\
\text { responsibility and } \\
\text { accountability." }\end{array}$ & $\begin{array}{l}\text { Critical } \\
\text { "the nature of volunteer } \\
\text { work is voluntary; } \\
\text { therefore, it challenges } \\
\text { traditional notions of work } \\
\text { and can create } \\
\text { opportunities to empower } \\
\text { marginalized communities } \\
\text { to challenge oppressive } \\
\text { systems." }\end{array}$ & $\begin{array}{l}\text { Traditional } 4 \mathrm{P} \\
\text { "academic-service } \\
\text { learning in liberal arts } \\
\text { courses can also give } \\
\text { students knowledge to } \\
\text { work in a range of } \\
\text { professional settings." }\end{array}$ \\
\hline
\end{tabular}

Figure 1. Framework and Corresponding Data Analysis Codes

Process of democratic engagement, traditional approach (1A): We coded statements similar to this one as falling under the traditional approach. The statement is suggestive of a process that leverages knowledge and learning as a way to make learning relevant to current issues.

Process of democratic engagement, critical approach (2A): An instance like this would fall under the critical approach because it suggests changing a system (curriculum development and economic system). The changed orientation announced is a specific learning process.

Value/purpose of democratic engagement, critical approach (3A): This instance would be an example of a critical approach to democratic engagement because it calls for the new value of 
building "sense of place." The critical approach represented in this statement is associated with "same place" in a way that challenges dominant understandings of place.

Value/Purpose of civic engagement, traditional approach (4A): This would be coded as a purpose value of civic engagement, from the traditional lens (it is not a new purpose, but one that is traditionally accepted in the field). Responsibility and accountability are values closely aligned with calls for civic-minded and socially responsible graduates.

Process of democratic engagement, traditional practice (1P): This instance was coded as such because application of real world skills is a traditional outcome and a process of civic engagement.

Process of civic engagement, critical practice (2P): This instance was coded as critical because it is suggesting a new approach to this work, particularly recognizing the voice of community and historically marginalized groups. By preparing students to engage community, students develop a critical practice on how best to work across difference and respond to power and marginalization.

Value/purpose of democratic engagement, critical practice (3P): This statement refers to the purpose of democratic engagement (a voluntary activity) and questions traditional interpretations of civic and public work.

Purpose of democratic engagement, traditional practice (4P): This is a traditional view of academic service-learning that would connect student development to career readiness.

Some instances were given two codes. For example, the suggestion was made that in the business sector, performance reviews should include civic identity and goals, even if they fall outside of an employee's immediate scope of work. This instance was coded as a critical approach, because it is suggesting a system change in performance reviews to include dimensions that challenge common assumptions of the for-profit sector. This instance would also be coded as a value/purpose and process of democratic engagement because by developing a civic identity and goals is both a purpose and process of democracy engagement (this instance had two codes, purpose/critical approach and process/critical approach).

\section{Analysis}

Data collected from the civic dialogue were coded according to the framework presented in the previous section. The framework maps the types of instances discussed during the civic dialogue. By categorizing instances within the framework, the data suggests ways in which community members, represented by participants from the National Conference on Volunteerism and Service, understand the intersection of civic leadership and the humanities, liberal arts, and social sciences. Our theming points to a predominant focus towards traditional aspects of civic leadership education and civic professionalism. More specifically, most instances reflected the practical, process orientation to civic leadership. 
Traditional "Instances" of Civic Leadership Education and Development. The instances from the civic dialogue indicate that the community perspective represented by participants at the National Conference on Volunteerism and Service community quickly moves towards considering civic leadership education and development from a traditional approach. In the majority of circumstances, efforts were centered on trying to leverage traditional processes of civic leadership education and development to redefine the practical relevance of academic fields. Community perspective represented by the National Conference on Volunteerism and Service often emphasized how liberal arts and civic leadership education could help students succeed in the systems that currently exist. Little to no attention was given to how the liberal arts and civic leadership education could prepare students to exercise leadership to make interventions towards a more just world.

In many circles, civic leadership and professionalism are tied to larger interests in preparing students and stakeholders to make change in their communities and professions. There was an implied element in our framing document, provocation, and facilitation strategy that one of the major components of civic leadership was to advance education and leadership development for some undefined change movement. However, the civic dialogue instances illuminate some confusion, contestation, and misunderstanding as to the larger objectives of change efforts tied to civic leadership and professionalism that extend from liberal arts, social sciences, and humanities education. It was difficult for participants to imagine a form of civic leadership that did not limit student learning to existing systems and potential career fields. Discussants did not appear to recognize the potential of civic professionalism to be interdisciplinary or to understand its role in developing well-rounded citizens that exercise leadership to remake systems, organizations, and institutions in new ways. Please refer to figure 2.

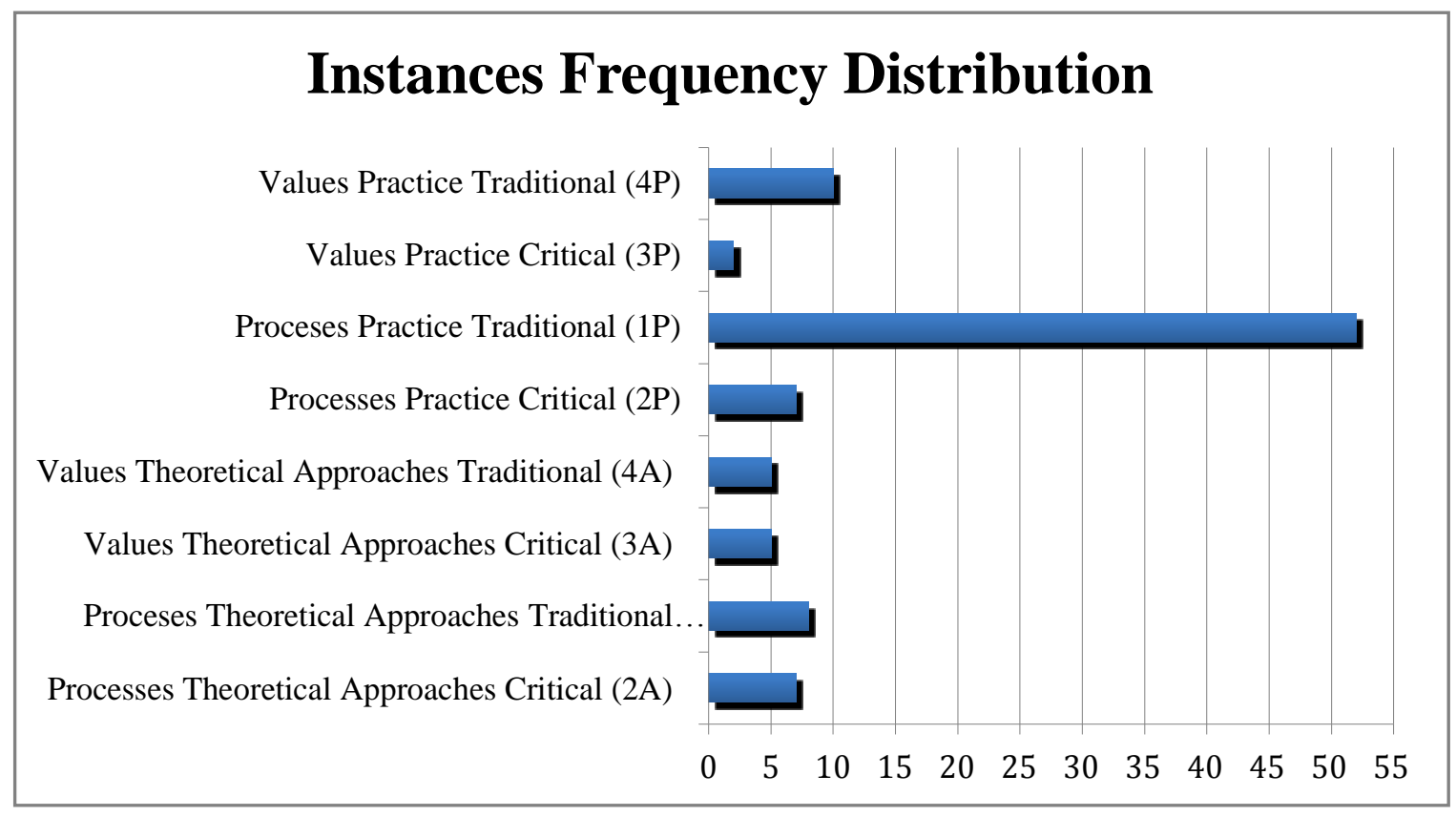

Figure 2. Instances Frequency Distribution 
The majority of civic leadership and professionalism instances were located in the traditional frame. Of the identified instances located within the traditional frame, a majority centered on issues of process, which involves leveraging current knowledge and procedures in developing civic professionalism rather than adopting a new practices. The data from the civic dialogue has implications for how stakeholders understand the relationship between civic leadership and the underlying values/purpose of a liberal arts, humanities, and social sciences education.

The location of instances within the coding framework (Fig. 2) provides insight as to how stakeholders commonly view change from a civic leadership and professionalism perspective. Traditional practices assumes that civic leadership and professionalism can help students' reform and fill existing gaps within current systems, organizations, and institutions. The location of instances from the dialogue points to a general presumption that the role of civic leadership and professionalism is to address deficits within existing structures, rather than question, challenge or address the causes of existing deficits.

The arrangement of the instances also points to the growing number of concerns that the liberal arts and humanities do not produce educational and practical outcomes that are aligned with the needs of society. The civic dialogue instances point to a slight tendency of stakeholders to assume that change movements, extending from civic leadership and professionalism, will be located within the traditional frame. This finding is significant because it begins to explain a general reluctance to radically change approaches to civic leadership and liberal arts education.

Implications. The tensions surfaced in this civic dialogue, point to factors that might be undermining the transformative potential of community engagement and civic leadership education and development. From a community engagement perspective, failing to recognize tensions between traditional and critical frames could lead to frustrated expectations that undermine community action and change efforts. The results of this civic dialogue and coding process illuminate a degree of nuance that helps explain perceptions of community engagement and civic professionalism from a social sector perspective. This nuanced understanding creates and opportunity to further explore how approaches to civic leadership education shape larger learning and development outcomes. Future research on leadership education should consider the consequence of having conflicting approaches to civic leadership education in a single experience. Effective community engagement invites community partners into the learning process as co-educators. If conflicting approaches to leadership education are present overall learning might be limited.

If civic leadership and liberal arts are understood in relation to existing systems, it is difficult to suggest alternative values and processes that could connect leadership learning to redefining systems, organizations, and institutions in our society. Education systems are crafted to meet the needs of society; thus, society must first indicate the need for shifts in the education of students and their preparation for the $21^{\text {st }}$ century workforce. Community engagement and its requisite campus-community partnerships are critical for thisinquiry, associated dialogues, and generating educational solutions, or interventions, to best meet the needs of communities at large. 
Future research and practice needs to more clearly articulate assumptions that inform change and reform movements associated with civic leadership and civic professionalism. Critical approaches to civic leadership and professionalism would require significant reexamination of research agendas, curriculum, and intent of practice. Critical approaches to civic leadership and professionalism would presume a theory of change, not anchored to filling existing deficits. Instead, critical approaches to civic leadership and professionalism would cultivate the types of skills, knowledge, and habits that can be used to remake troubled systems, organizations, and institutions. The theming process highlights the need for our field to distinguish the basis and justification between traditional and critical approaches with our community partners. Furthermore, the results of this dialogue begin to surface larger implications when community engagement and civic professionalism is connected primarily to social and emergency services. If a student's civic professionalism experience is limited to responding to emergency needs, there is never really an opportunity to examine systems that produce the need for emergency services in the first place. The inability to see beyond traditional approaches to civic leadership and civic professionalism might help explain why students and community approach this work from primarily a charity lens (see Boyle-Baise \& Langford, 2004; Mitchell, 2007). Future research and practice needs to explore how leadership educators can engage community in more complex conversations on the relationship between traditional and critical approaches to civic leadership.

Understanding how stakeholders distinguish between critical and traditional forms of civic leadership and professionalism is paramount in understanding the purpose of our field. The instances from our dialogue indicate the many participants viewed and understood civic leadership and professionalism primarily from a process perspective. Process interpretations of civic leadership and professionalism were seen in how participants discussed and thought about the curriculum, teaching methods, experiential learning opportunities, and overall goals of a liberal arts and humanities education that included civic leadership education components. We developed two primary orientations to understand the location of civic dialogue instances within the traditional process space. We interpret the civic dialogue instances as also highlighting an anxiety around how values relate to the larger project of civic leadership education and development.

Process, in many ways, can be discussed, framed, and considered from a value-neutral perspective. Our field notes capture a range of ways participants were comfortable discussing process from a value-neutral and value-less perspective. However, process discussions from a substantive perspective seemed to be missing from our civic dialogue. The aversion to values can be connected to a general inability of the field to recognize and accommodate political contestation. Political contestation refers to a space in which reasonable people could disagree on the actual meaning of specific values and process of democratic engagement and civic leadership. Creating the capacity to handle political contestation will be the only way to more effectively consider and outline relevant values of civic leadership and professionalism.

The results of this study call for an examination of the intended outcomes of leadership education and the liberal arts. If a critical approach to civic engagement and liberal education were embraced, along with space for political contestation, educators and students might be empowered to question the causes and structures of societal deficits and engage in our 
communities in ways that produce positive and lasting change. This would move civic engagement beyond public service to examining structures, questioning the status quo, and involvement in political action that addresses the causes of existing deficits and leads to positive and lasting community change.

\section{Conclusion}

The 21 st century will be challenging for both higher education and the field of civic leadership education. The traditional role and understanding of higher education and civic leadership will need to evolve in order to respond to societal needs and changes. A key element of any change or reform effort is that it is completed intentionally.

Without critical examination and intentional reform the public relevance of knowing, understanding and experiencing will slowly decline. The liberal arts and humanities are a fundamental element of understanding the world in which we live and imagine what the world might be. In fact, it can be argued that understandings of oppression and understandings of how the world needs to change often occurs while studying the liberal arts, humanities, and social sciences.

Continuing to consider how civic leadership education and development can extend from the liberal arts, humanities, and social sciences will help prepare students to be conscious and active citizens. Efforts to protect a space for civic leadership and civic professionalism are essential for our society to respond to the social, political, economic, cultural, and environmental challenges of the 21 st century.

\section{References}

Boyle-Baise, M., \& Langford, J. (2004). There are children here: Service learning for social Justice. Equity and Excellence in Education, 37(1), 55-66.

Boyte, H., \& Fretz, E. (2010).Civic professionalism. Journal of Higher Education Outreach and Engagement, 14 (2), 67-89.

Buschlen, E., Warner, C., \& Goffnetts, S. (2015). Leadership education and service: Exploring Transformational learning following a tornado, Journal of Leadership Education, 14(1), $33-54$.

Butin, D. (2013). Provocation: On the future of the civic in a disrupted university (pp. 1-12). Scott L. Crabill and Dan Butin (Eds.). Community engagement 2.0? Dialogues on the future of the civic in the disrupted university. New York: Palgrave Macmillan.

Chrislip, D., \& O’Malley. (2013). For the common good: Redefining civic leadership. Wichita: KLC Press. 
Duarte, G. (2015). Chapter 18: Mi Casa Es Tu Casa: A Framework for Reciprocal Public Benefit."In M. Larsen (Ed.), International Service Learning: Engaging Host Communities. London: Routledge.

Ehrlich, T. (2000). Civic responsibility and higher education. Westport, CT: Oryx Press.

Emerson, M.E., Fretz, R. I., \& Shaw, L. L. (1995). Writing ethnographic fieldnotes, Chicago: The University of Chicago Press.

Ganz, M. (2010). Leading change: Leadership, organization, and social movements. In N. Nohira and R. Khurana (Eds.), Handbook on Leadership Theory and practice: A Harvard Business School Centennial Colloquium. Cambridge, MA: Harvard Business Review Press.

Gastil, J. (2008). Political communication and deliberation. Thousands Oak, CA: SAGE.

Grunwell, S. G. (2015). Leading our world forward: An example of student leadership Development, Journal of Leadership Education, 14(2), 82-99.

Heifetz, R., Grashow, A., \& Linsky, M. (2009). The practice of adaptive leadership: Tools and tactics for changing your organization and the world. Boston: Harvard Business Press.

Holsapple, M. A. ( 2012). Service-learning and student diversity outcomes: Existing evidence Directions for future research, Michigan Journal of Community Service Learning, 18(2), 3-18.

Imagining America. (2010). Civic professionalism: A new paradigm for undergraduate Liberal arts education, Paper 9, http://surface.syr.edu/ia/9.

Kayser, A. G., Lima, M., \& Lundy, G. (2013). Do universities communications about campusCommunity partnerships reflect core engagement principles? Michigan Journal of Community Service Learning, 21(1), 41-52.

Lagemann, E., \& Lewis, H. (2011). What is college for? The public purpose of higher education, New York: Teachers College Press.

Mitchell, T. (2007). Critical service-learning as social justice education: A case study of the Citizen Scholars Program, Equity and Excellence in Education, 40(2), 101-112.

Mitchell, T. (2008). Traditional vs. critical service-learning: Engaging the literature to differentiate two models. Michigan Journal of Community Service Learning, 14(2), $50-65$. 
NERCHE (New England Resource Center for Higher Education). Retrieved on January 13, 2015 http://nerche.org/index.php?option=com_content\&view=article\&id=341\&Itemid=92\#CE\%20def.

Polk, D. (2014). Forces for positive change: Preparing leaders for positive change: Preparing Leadership for the $21^{\text {st }}$ century in an undergraduate Honors program, Journal of Leadership, 13(1), 1-13. Education, 13(2), 140-151.

O’Meara, K. (2011). Faculty Civic Engagement: New training, assumptions, and markets needed for the engaged American scholar (pp. 177-198). John Saltmarsh \& Matt Hartley, (Eds.). "To serve a larger purpose:" Engagement for democracy and the transformation of higher education. Philadelphia: Temple University Press.

O’Meara, K., \& Jaeger, A. (2006). Preparing future faculty for community engagement: Barriers, facilitators, models, and recommendations. Journal of Higher Education Outreach and Engagement, 11(4), 3-24.

Priest, K., Bauer, T., \& Fine, L. (In press). The hunger project: Exercising civic leadership with the community for the common good in an introductory leadership course. Journal of Leadership Education.

Peters, S. J. (2004). Education the civic professional: Reconfiguring and resistances, Michigan Journal of Community Service Learning, 11(1), 47-55.

Pompa, L. (2002). Service-learning as crucible: Reflections on immersion, context, power, and transformation. Michigan Journal of Community Service Learning, 9(1), 67-76.

Slaughter, S. \& Rhoades, G. (2004). Academic capitalism and the new economy: Markets, state, and higher education. Baltimore: The John Hopkins University Press.

Steinberg, K. S., Hatcher, J. A., \& Bringle, B. G. (2008). Civic-Minded Graduate: A North Star. Michigan Journal of Community Service Learning, 18(1), 19-33.

Sullivan, W. M. (2005). Work and integrity: The crisis and promise of professionalism in America. San Francisco: Jossey-Bass.

Sullivan, W. M., \& Rosin, M. S. (2008). A life of the mind for practice: Bridging liberal and professional education, Change, 40(2). 44-47. 


\section{Author Biographies}

Brandon W. Kliewer, Ph.D. is currently an assistant professor of civic leadership in the Mary Lynn and Warren Staley School of Leadership Studies at Kansas State University. Brandon specializes in deliberative civic engagement, community-engaged scholarship, and cross-sector collaboration forms of civic leadership activity.

Kristin N. Moretto, Ph.D. is the Director of Experiential Learning in the College of Public Health at the University of South Florida. Her areas of expertise include service-learning, communityengaged scholarship, field experiences and building community partnerships.

Jennifer W. Purcell, Ed.D. is an assistant professor of leadership studies in the Department of Leadership and Integrative Studies at Kennesaw State University. Her research explores leadership and organizational development within institutions of higher education. 